\begin{tabular}{|l|l|l|}
\hline \multicolumn{2}{|c|}{ PublisherInfo } \\
\hline \hline PublisherName & $:$ & BioMed Central \\
\hline \hline PublisherLocation & $:$ & London \\
\hline \hline PublisherImprintName & $:$ & BioMed Central \\
\hline \hline
\end{tabular}

\title{
Anthrax-induced apoptosis
}

\begin{tabular}{|l|l|l||}
\hline \multicolumn{2}{|c|}{ ArticleInfo } \\
\hline \hline ArticleID & $:$ & 4569 \\
\hline \hline ArticleDOI & $:$ & $10.1186 /$ gb-spotlight-20020903-01 \\
\hline \hline ArticleCitationID & $:$ & spotlight-20020903-01 \\
\hline \hline ArticleSequenceNumber & $:$ & 235 \\
\hline \hline ArticleCategory & $:$ & Research news \\
\hline ArticleFirstPage & $:$ & 1 \\
\hline \hline ArticleLastPage & $:$ & 2 \\
\hline \hline & & RegistrationDate : 2002-9-3 \\
\hline ArticleHistory & $:$ & OnlineDate \\
\hline \hline ArticleCopyright & $:$ & BioMed Central Ltd2002-9-3 \\
\hline \hline ArticleGrants & $:$ & \\
\hline \hline ArticleContext & $:$ & 130593311 \\
\hline \hline
\end{tabular}




\section{Jonathan B Weitzman}

Email: jonathanweitzman@hotmail.com

The Bacillus anthracis bacterium evades the host immune system by inducing macrophage apoptosis via the activity of anthrax lethal factor (LF). In the August 29 Sciencexpress, Park et al. describe the involvement of mitogen-activated protein (MAP) kinase pathways in anthrax-induced apoptosis (Sciencexpress, 29 August 2002, DOI:10.1126/science.1073163). They found that low concentrations of LF caused rapid apoptosis of macrophages activated by lipopolysaccharide. Park et al. used inhibitors of specific MAP kinase pathways and mutant kinase isoforms to demonstrate that LF-induced cleavage of the MAP kinases MKK3 and MKK6 and inhibition of the p38 MAP kinase pathway leads to apoptosis. Experiments with mutant mouse cells also demonstrated the role of the NFKB transcription factor in protecting against LF-induced apoptosis. The authors propose that $\mathrm{p} 38$ synergizes with NFkB to drive the expression of a set of target genes that protect against cell death. Thus, the anthrax bacterium has developed an approach to avoid detection by inducing the death of activated macrophages.

\section{References}

1. Anthrax toxins.

2. Sciencexpress, [http://www.sciencexpress.org] 